\title{
WELLNESS AND THERMAL TOURISM: AN INSIGHT FROM ITALY
}

\author{
Antonietta Ivona ${ }^{1}$ \\ Adrian Nedelcu ${ }^{2}$ \\ Alexandru Ganusceac ${ }^{3}$ (i) \\ Donatella Privitera ${ }^{4}$
}

DOI: https://doi.org/10.31410/tmt.2019.77

\begin{abstract}
Wellness and thermal tourism is changing at national and international levels even taking in account the growth rates of, and changes in, global consumption patterns. In this context, the objective of this study is to track a view on thermal tourism in Italy, focusing on a case study in the Apulia region. The primary function is therefore to establish important territorial safeguards aimed at satisfying the health demands of the population, while complying with the principles of therapeutic appropriateness and managerial efficiency. The analysis highlights the need to continue developing knowledge in a sector with great growth potential, especially in European countries.
\end{abstract}

Keywords: Health Tourism, Apulia Region, Case study, Thermalism.

\section{INTRODUCTION AND BACKGROUND}

$\mathrm{R}$ ecently wellbeing, wellness and relaxation are among the many concepts to become associated with tourism and have become the focus for a number of tourism studies, which highlight the analysis of wellness tourism as a phenomenon. The concept of wellbeing, for example, especially the subjective wellbeing of those who travel, has received empirical attention (Nawijn, 2011). It has been defined as, "a broad category of phenomena that includes people's emotional responses, domain satisfactions and global judgments of life satisfaction" (Diener et al., 1999, p. 277). Wellbeing includes a mix of factors: the relative absence of anxiety and depression, frequent and intense positive affective states, and global life satisfaction (Diener et al., 1999). Wellbeing and health are one of the themes of the new millennium; the tendency of individuals to be concerned with their body and good physical fitness reflects the necessity we have of being healthy and even staying young, permanently searching for a better quality of life (Ramos, Santos, 2002).

What does the term wellness mean and how can we define it? The Global Wellness Institute (GWI) defines wellness as a continuous activity consisting of several activities, choices and lifestyles that lead to a holistic state of health (GWI, 2018).

For some, this can mean connecting with nature and the environment and for others, wellness means spending time in a pleasant and relaxing atmosphere. Regardless of the way you use it, it is certain that for most of us, wellness means connecting with yourself to feel better and restore your health, both physical and spiritual.

$1 \quad$ University of Bari Aldo Moro, Piazza Umberto I, No.1, 70121, Bari, Italy

2 Petroleum-Gas University of Ploiesti, Faculty of Economic Sciences, Ploiesti, No. 39, Bucharest Avenue, Prahova County, 100680, Romania

3 Faculty of Geography, University of Bucharest, No. 1, Nicolae Bălcescu Avenue, 010041, Bucharest, Romania

4 University of Catania, Department of Educational Sciences, No. 4 Via Biblioteca, 95124, Catania, Italy 
If we are still talking about connection, it is worth mentioning that in the last decades the connection between people has been replaced by the connection from the point of view of technology, this being more and more present in our lives as time goes by.

Although the main mission of the technological interconnection is to significantly improve the lives of people, through processors, gadgets, applications and programs based on AI (the artificial intellect) the most precious good that a person can have, that is, time, began to be stolen even by the above- mentioned elements. We all started to be locked in a kind of bubble, that space - called in modern word "privacy", which we all hold so much. As we are increasingly bombarded with messages, emails and different news that must be interesting from the point of view of the computing algorithms used by different companies and commercial.

Travelling for health purposes is a global tourism trend. Health tourism is very popular around the world, from America to Malaysia, the number of interested people is growing year on year and the forecast is that it will continue on this upward path. This is of great importance in terms of attracting tourists, in both high and low seasons. Numerous countries have identified health, medical and wellness tourism as a key development area. The wellness tourism economy was worth 639 billion USD in 2017 (GWI, 2018). All tourism sectors will continue to add more wellness elements, and wellness tourism experiences will become more sophisticated. The wellness movement has become mainstream, both at the individual and the corporate levels, and the healthcare industry is considered to be of strategic interest. Various social, political, and economic factors, as well as technological innovations, shape this demand, as well as the supply of wellness and medical services (UNWTO, 2019). To this concept of wellbeing is linked thermal tourism, in a new version of wellness, based on a new concept of experience, including wellness tourism, which is different to health tourism. In fact, Ramos and Santos (2002, p. 3) affirm that thermalism includes "immediately to indication and using of thermal water with illness treatment recognized virtues", so thermal tourism implies pleasure with this kind of activity in specific centers or institutes, but it is also associated with a healthier life, where sometimes it is applied without a specific illness, but is preventative, playful and focused on wellbeing. Spas are defined by the GWI (2018, p. 11) as, "establishments that promote wellness through the provision of therapeutic and other professional services, animating and renewing the body, mind and spirit". Spas are often mentioned in tandem with wellness but they are a means of engaging in wellness and they have a strong appeal to visitors. Spas and wellness together promote health and wellbeing and, as a tourism product, also have a significant impact on the visitor economy, local communities, and the natural resources of touristic destinations.

Across the world, Europe remains the destination for the highest number of wellness trips (Figure 1). North America continues to lead in wellness tourism expenditure because the average spending per trip is higher. In the past five years, Asia has made the most gains in the number of wellness trips and wellness tourism expenditure, with demand stimulated by strong economies and an expanding middle class.

Italy is a European country with numerous thermal establishments, due to its particular geological conformation, rich in volcanic rock and sulphured water springs. Italy has already earned some popularity as a tourist destination in this regard. According to Federterme (2018), in Italy, there are 323 thermal establishments with accreditation by the National Health Service, with about 65,000 employees, distributed across all regions of the country (except Molise) but concentrated in the Veneto region (28.2\%) and in Campania (23.8\%), regions rich in mineral 
water sources: then comes Tuscany (6.2\%), Emilia-Romagna (7.1\%), Lazio (4\%), and Lombardy (3.7\%) (www.federterme.it). The distribution is influenced by the incidence of traditional establishments or new resorts with wellness services (Rocca, 2014) close to thermal water springs. Each resort has its own purpose and every water is used to treat different diseases. In 2018, the total revenues of the sector were close to $€ 760$ million (provisional data of Ebiterme, 2019), divided between $€ 118,9$ millions of affiliated spa treatments and $€ 639,5$ million of additional services, such as accommodation, cosmetic medicine, fitness, etc.

In the new version of wellness and thermal services, the role of internet is critical for thermal destinations, where a smart tourist destination promotes its image with a 'intelligent' presence on the web, and creates virtual heritage, generating and promoting creative and cultural activities that enrich and consequently qualify the urban region (Privitera, 2017, p. 24). Specifically, in the area of wellbeing, sports and health technology are increasingly being used to inform people about health and sports activities, or just knowledge of the health and therapeutic services offered. Thermal tourism destinations are a consumption point of complex activities that comprise the tourism experience and the internet provide a virtual journey. Health and thermal resorts and spas have the capacity to meet leisure, tourism and healthcare needs in one place (Tabacchi, 2010). It is worth highlighting the capacity of these centers to achieve the development of the region and the local economy in which they operate (generally located in rural areas), creating employment and generating income (Quintela, Costa, 2015).

This study provides a profile of the thermal sector in Italy, highlights the potential regarding the development of wellness tourism linked to thermal tourism, and the factors that attract and motivate this alternative form of tourism in the Apulia region (in the south of Italy), where it can contribute to the socio-economic development of the region, through investments and rapid results.

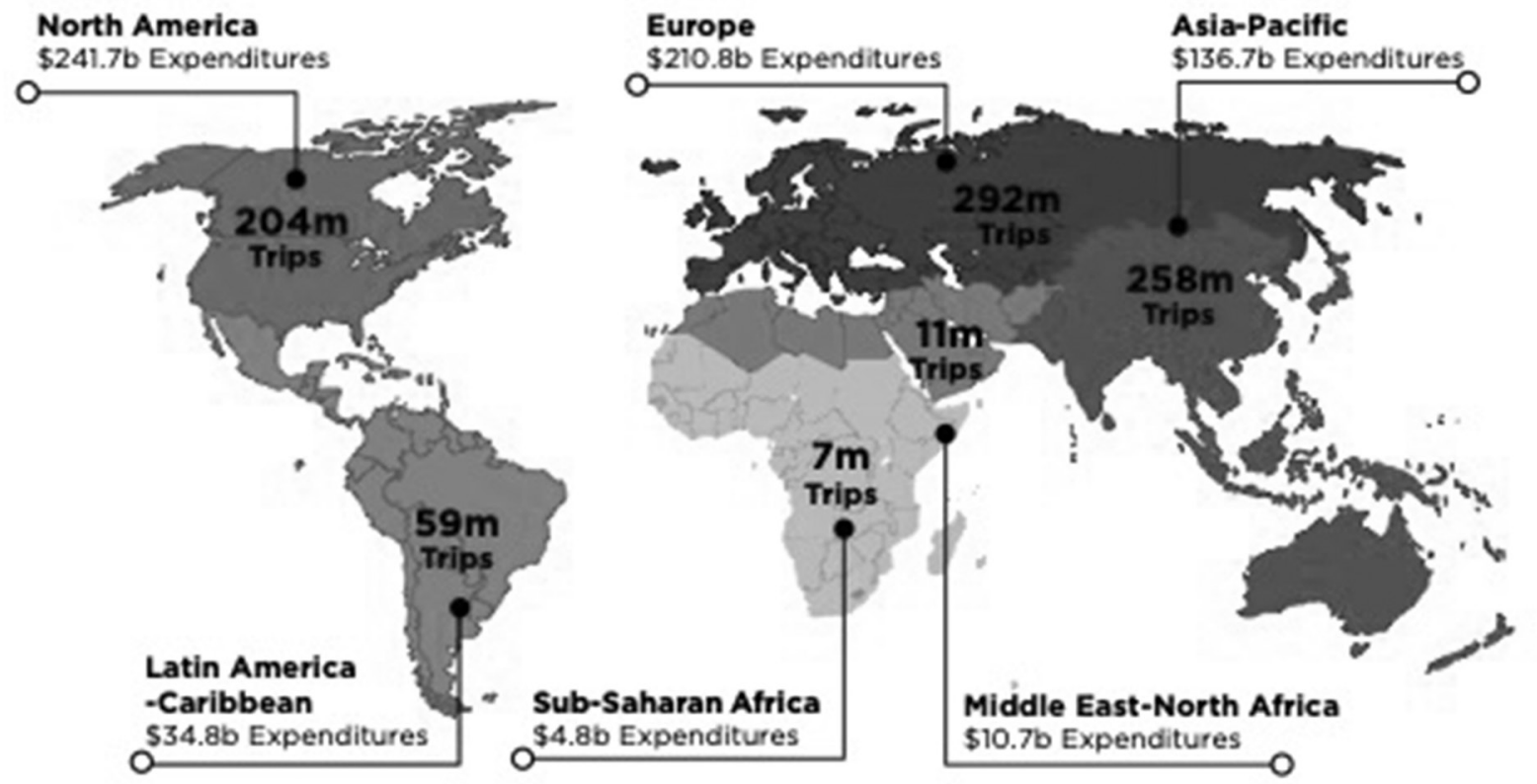

Figure 1. Wellness tourism by region, 2017. Number of wellness tourism trips and expenditures (inbound and domestic)

Source: GWI, 2018, p. 11 


\section{RECENT CHANGES IN THERMAL TOURISM IN ITALY}

In Italy, thermal tourism, an ancient form of health tourism, is going through a phase of transformation that describes rather varied scenarios in the landscape of enjoyment and facilities management (Rocca, 2014). The final product is a composite of the components of care, a wellness region, with tourism creating a "wellness industry" (Gregori, Cardinali, 2012, p. 17) where traditional structures have been called on to implement digital transformation.

The terms 'wellness', 'care' and 'thermal' are sometimes used as synonyms, creating confusion among operators, users, institutions, and tourists. Italian Law 323 of 2000 on the "reorganisation of the thermal system", defines the terms "care" and "wellness", in addition to regulating the supply of spa services and introducing provisions on the promotion and upgrading of hydrothermal heritage in relation to the enhancement of the natural and cultural resources of spa regions. This is linked to what is contained in the following law on the reform of the national legislation on tourism of 29 March $2001 \mathrm{n}$. 135, which sought to highlight the role of local institutions in the management and development of spa resources. Thermal baths have become an integral part of a region, in which the spatial relations, even those of hierarchical type, play a central role. It is necessary to say that there are many categories and types of thermal and mineral springs establishments in the world, as GWI (2018) highlights (Figure 2).

\begin{tabular}{|c|c|c|}
\hline $\begin{array}{c}\text { Primarily } \\
\text { Recreational }\end{array}$ & $\begin{array}{l}\text { Primarily } \\
\text { Wellness }\end{array}$ & $\begin{array}{c}\text { Primarily } \\
\text { Therapeutic or Curative }\end{array}$ \\
\hline $\begin{array}{l}\text { Thermal/mineral water } \\
\text { swimming pool facilities }\end{array}$ & $\begin{array}{c}\text { Thermal/mineral water } \\
\text { bathing facilities }\end{array}$ & \multirow{2}{*}{$\begin{array}{l}\text { Health resorts and sanatoria } \\
\text { that use thermal/mineral } \\
\text { waters for treatments }\end{array}$} \\
\hline $\begin{array}{l}\text { Thermal/mineral } \\
\text { water-based waterparks }\end{array}$ & $\begin{array}{l}\text { Thermal/mineral } \\
\text { water-based spas }\end{array}$ & \\
\hline $\begin{array}{l}\text { Hotels/resorts with thermal/ } \\
\text { mineral water swimming pools }\end{array}$ & \multicolumn{2}{|c|}{ Thalassotherapy spas and resorts } \\
\hline \multicolumn{2}{|c|}{ Thermal or hot springs resorts } & \\
\hline
\end{tabular}

Figure 2. Types of thermal/mineral springs establishments

Source: GWI, 2018, p. 13

In Italy, the sector is characterized by an increasingly integrated trend: a continuous reduction in traditional performance and an increase in wellbeing. It is called the 'sixth generation' of thermal activity, where aesthetic treatments are added, and fitness and tourist services are increasingly linked to the regional offer in terms of cultural and gastronomy trips.

More recently, spas and wellness centers have tended to apply a wellbeing-oriented approach to the whole operation and differently for separate markets or countries (Puczkó, Smith, 2018). Usually, wellness and spa services are more convenient in markets where there is a significant supply of spa facilities, mainly based on natural resources. One example is Japan, the country with the largest number of thermal establishments, where there has been an improvement in the health system with the integration of traditional medical centers using thermal spas. These centers not only help to meet current needs and maintain the tradition and culture of the population, but have also contributed to the development of the regions through the commercialization of rural areas with the climatic and 
geographical conditions that allow the creation of commercial resources and therefore economic diversification of these areas (Tabayashi, 2010, p.121). In fact, spas and wellness help the local community, may bring meaningful employment to them, and create spin-off economic opportunities for items such as wellness souvenir production and supplying treatment supplies to the spa. An example where the growing demand of spas benefits entrepreneurs financially is jasmine massage oil processing in Thailand and Bali (Lo, 2019).

Another example is Turkey, where the development of thermal tourism has prehistoric origins and lifestyle and traditional uses (the famous Turkish baths). Since 2007/08, following major investments in modern renovation of traditional treatment rooms (hotel and/or resort versions) joined by the offer of medical therapies, Turkey has become one of the world's leading countries in terms of health and wellness tourism (Kervankiran, 2016, p. 116).

In Italy, thermal structures are not necessarily connected to accommodation units but many of them tend to be an autonomous activity, redeveloped for the supply of therapeutic diagnostic services where prevention (rather than rehabilitation) is the stimulus for wellbeing (Dai Prà, 2013, p. 8). Recently, many success stories have come from resorts exclusively oriented to wellness tourism; other centers have evolved with the integration of spa treatments, rehabilitation, and healthcare, leading to a clear distinction between residential services (e.g., wellness farms) and non-residential services (day spas, thermal baths, fitness/wellness centers).

There are markets in different countries where wellness and spa facilities are positioned predominantly in the upmarket and luxury brackets but markets show a high degree of differentiation in terms of target segments. However, in recent times the preferred target audience for wellness and spa services appears to be young couples and groups of friends, while adults and the elderly (52\% of the total) is oriented to traditional spa facilities (Puczkó, Smith, 2018, p. 16). In fact, wellness and spa operators need to pay more attention to those guests who may not be core wellness guests, but show a growing interest in, and demand for, healthy options at a hotel, resort, spa, or baths. The Virtuoso Luxe Report identified services for wellness to be massage and other physical treatments, fitness lessons, beauty with use of natural products, combined with healthy cuisine (Virtuoso Life, 2017). Today more than ever, wellbeing as such incorporates the integration of mind, body and soul. In fact, the hospitality industry is continuing to explore ways to capitalize on the wellness trend, and most are looking in the spa and healthy dining directions. To this end, and with the younger generations increasingly wanting relaxation and wellness while travelling, the spa and fitness center has become a major selling feature for hotels. However, the wellness center not only represents a place for bodily improvement but also one for meeting new people and positive interactions.

Data on expenditure on the demand for wellness and spa services confirm that, compared to traditional services, it is relatively high (Table 1). In Italy, spas are not luxurious, only in a few cases are they associated with high-class resorts; therefore, they are generally more affordable. In comparison with wellness services, spa treatments are an offer of democratized wellness, as they are accessible to most market segments, following agreements with Italy's National Health Service. The most popular services in spa centers, namely health-oriented treatments, are positioned in the mature phase in the life cycle of wellness products, and need to be revitalized or added to in order to create more revenue. Health treatment options at spas and wellness facilities, as well as in hotels, can create additional demand from health-conscious market segments, but not necessarily tourism. Not surprisingly, the international demand for wellness and spa services during a tourist trip, combined with the enjoyment of cultural activities, represents the highest spending segment. 
Table 1. Guest spending for wellness/spa/thermal services, 2018 (euro/person)

\begin{tabular}{|c|c|c|c|c|}
\cline { 2 - 5 } \multicolumn{1}{c|}{} & \multicolumn{3}{c|}{ Wellness/spa Services } & $\begin{array}{c}\text { Thermal } \\
\text { Trattament }\end{array}$ \\
\hline Users & World & Europe & Italy & 75 \\
\hline International & 161 & 127 & 163 & 58 \\
\hline National & 145 & 99 & 163 & 12 \\
\hline Local & 91 & 42 & 83 & \\
\hline
\end{tabular}

Source: Puczkó, Smith, 2018, p. 28-29

The spa tourism sector is also positively affected by the use of technology and services offered in the virtual world. The sector recognizes the value of web marketing, equal to at least $1 \%$ of turnover, and the digital transformation is most evident in accommodation facilities $(67.2 \%$ of firms or hotels), where the take-up rate of digital tools is high for both promotional (89\%) and booking activities (ISTAT, 2017). Technological changes and the implications for spa tourism are highlighted in the growing use of online platforms or applications, where it is possible to promote, highlight and differentiate the products offered, not only as a characteristic and distinctive feature of business opportunities for operators but also as social interactions with potential customers. In fact, the use of smart technologies for experiential and interactive tourist enjoyment is preferred and profitable in the case of wellness routes. Specifically, applications for mobile devices link and underlie positioning and georeferencing technologies, leading to a textured story of the geographical space, in which images are combined and re-combined, increasing real and illusory information by providing access to ever-increasing amounts of visual information (Thielmann, 2010, p. 7).

\section{A CASE STUDY: THE IMPORTANCE OF THERMAL TOURISM IN APULIA REGION}

\subsection{The Apulian Tourism Context}

Tourism in Apulia has undergone positive changes in recent years; in 2019 the internationalization rate reached $28 \%$ for arrivals and $25 \%$ for presences / overnight stays. Compared to 2015, the internationalization rate of incoming has increased by 7 percentage points (Figure 3). The foreign presence is more evident in the summer and, in particular, in July ( $18 \%$ of the annual total) and September (17\%). In the other months the presence is generally constant, with a few peaks or at particular events or during the holidays (at Christmas and especially at Easter). In 2019 the months with the highest increases were August (60 thousand more arrivals, $+8 \%$ on 2018), October (+ 30 thousand, $+11 \%)$, April (+ 20 thousand, $+7 \%)$ and May $(+18$ thousand, $+5 \%)$.

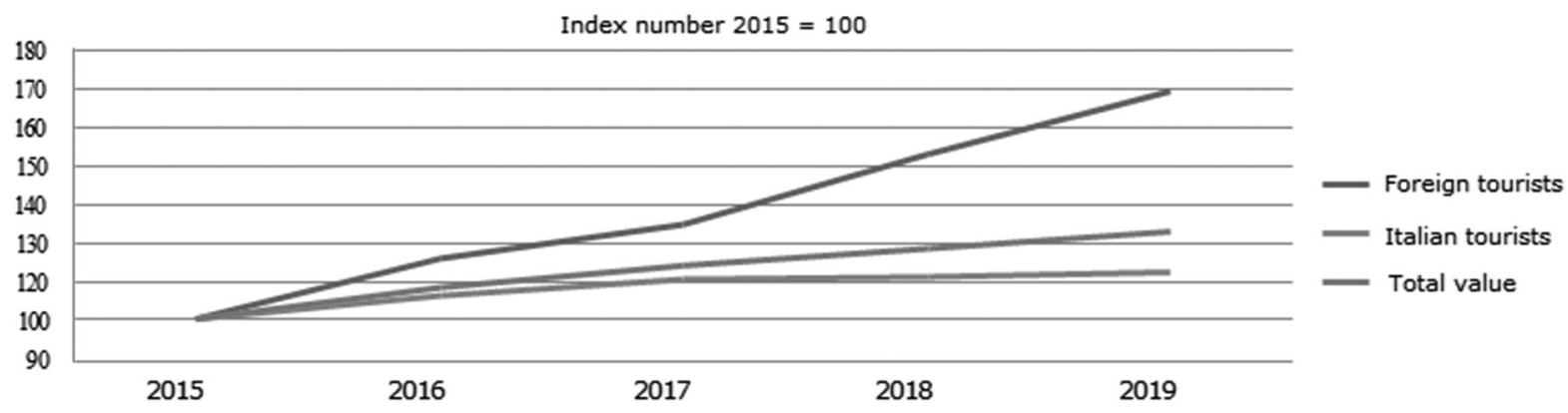

Figure 3. Trend of arrivals in Apulia region

Source: Authors on data of the Puglia System for the Tourist Observatory and ISTAT 2019 
The biggest increase, in the last two years, of tourists by nationality is registered from Russia (+ $47 \%$ ), Romania (+25\%), Poland and Brazil (+23\%), Netherlands (+ 17\%), and Australia (+ 16\%). The increase concerned both the number of arrivals and overnight stays.

An analysis of the data divided by the six Apulian provinces shows that the main destination for tourist incoming (arrivals) in 2019 is the province of Bari with a percentage share of the total of $28 \%$. The two main tourist centers for the number of overnight stays remain Gargano (north of the province of Foggia) and Salento (the southern part of the province of Lecce), with a territorial share of $28 \%$ and $31 \%$ respectively.

Compared to the other Italian regions, Puglia is in eighth place in terms of overall attendance with a share of $3.54 \%$ of the national total, after Veneto, Trentino Alto Adige, Tuscany, Emilia Romagna, Lombardy, Lazio and Campania.

Although the number of non-hotel structures in Apulia is growing at a rapid speed $(+46 \%$ compared to 2015), the accommodation capacity of the region has remained almost unchanged over the years $(284,250$ total beds in 2019 with a variation of $+3 \%$ compared to 2015$)$. In 2019, 7,950 accommodations were registered in Puglia, of which $13 \%$ in the hotel category (38\% of regional beds). The overall increase in the number of facilities was of $+40 \%$ from 2015 to today.

In short, the tourism sector is currently fundamental for the entire regional economy as can be deduced from the comparison of the regional GDP with that deriving from tourism activities (Figure 4).

The value of tourism in Puglia is around 6.5 billion (12.3\% of total consumption). The estimated added value is 9 billion ( $13.6 \%$ of the total). The data on the companies are also very significant: a total of 52,000 companies are involved in the sector (38\% of the total) with 135,000 employees $(15.4 \%$ of the total) directly and indirectly involved. According to Bankitalia, international tourist spending in Apulia increased by $+3 \%$ from January to September 2019.

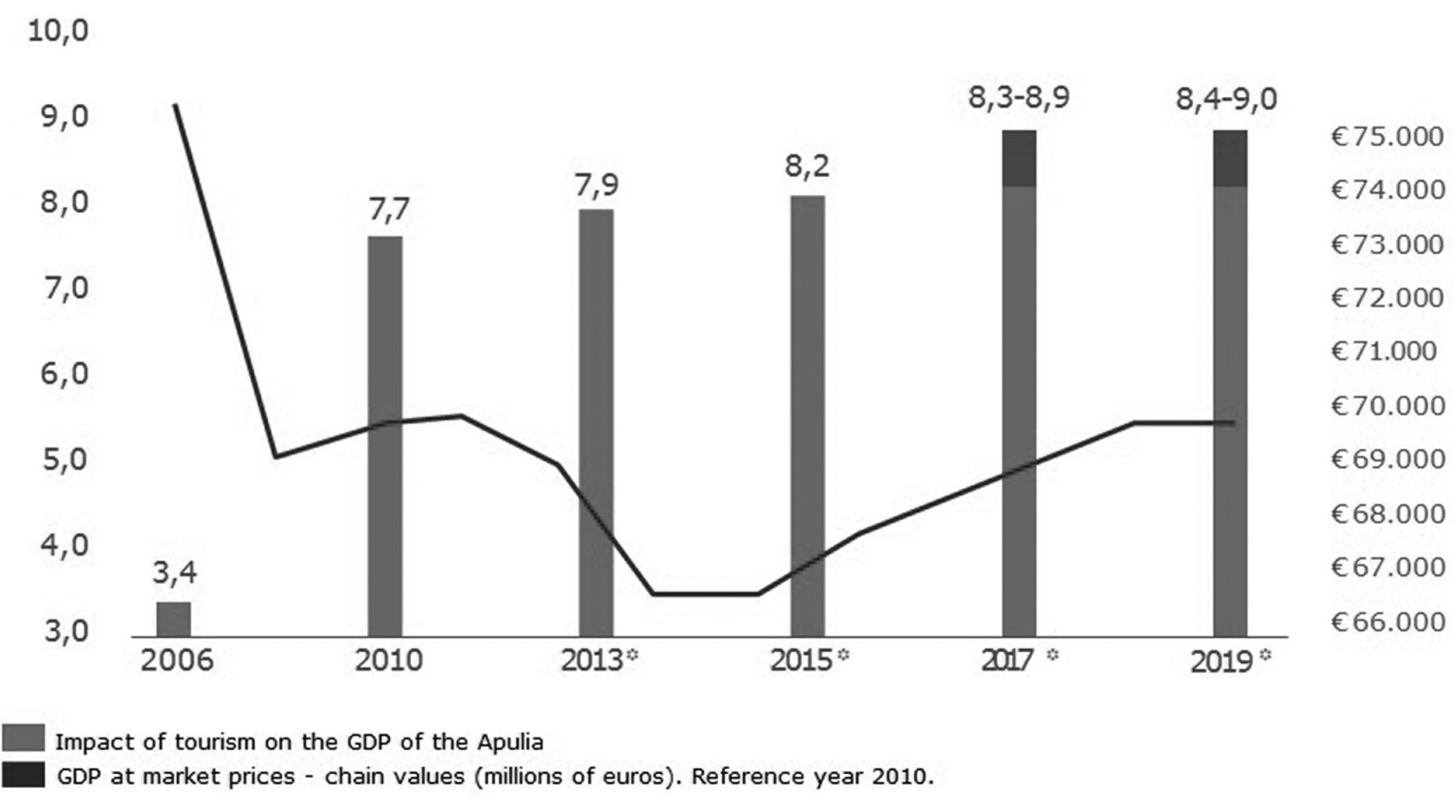

Figure 4. The incidence of tourist GDP of the Apulia

Source: Puglia Promozione, 2019, adapted 
Based on an analysis of the tourism market in Puglia, it emerges how the thermal sector represents an important market niche in the region. Despite the marginal weight on the tourism economy, the wellness product nevertheless presents interesting average growth rates as it is linked to the seaside sector. This type of tourism, once linked to the concept of health, is now evolving from the traditional thermal level to that of well-being that integrates with body treatments and psycho-physical regeneration, nature, artistic and food and wine beauties of a territory.

\subsection{Thermalism from an Italian Regional Perspective}

According to the latest Ebiterme (2018) surveys, at the end of 2017, there were 321 hydroponic and hydrotherapy establishments in operation in Italy, $90 \%$ of which carried out their activity under the accreditation regime of the National Health Service (Figure 5). This means that Italian operations not only use mineral water that is effective in treating various chronic diseases and enable functional rehabilitation, but also meet the structural, organizational and professional requirements necessary to be able to operate on behalf of public health (adequacy of facilities, availability of personnel with specialized skills, accessibility and quality of care, compliance with health and hygiene regulations, etc.). Their primary function is, therefore, to establish important safeguards aimed at satisfying the health demand of the population, in compliance with the principles of therapeutic appropriateness and managerial efficiency.

The spas are located in 153 municipalities and consist of 62 spa resorts, 22 seaside locations, 13 heritage cities, 12 mountain resorts, six hill towns, five lake resorts, and 34 other types of locations. Excluding the three urban cities equipped with thermal centers (Naples, Genoa and Bologna), the locations in question are generally characterized by their reduced demographic density, with about 10,000 inhabitants in the north, about 13,000 in the central area, and about 15,000 in the south. The locations of the hydrotherapy establishments show a marked capacity for accommodation, bearing in mind that they have 5,346 hotels with over 401,000 beds (compared to 2,248,000 thousand hotel beds surveyed by ISTAT at the national level). Naturally, the share of beds in seaside resorts with establishments (equal to 55.5\%) exceeds that of spa resorts $(27.3 \%)$ and other tourist sites (17.2\%).

The hotels owned by the spa companies, often called 'hotel Therme', have a total of around 30,000 beds, corresponding on average to just over 100 beds for each structure. This is an appreciable figure especially considering two circumstances. Firstly, some large parks and spas do not have their own accommodation facilities and make use of agreements with adjacent facilities. Secondly, almost all the accommodation capacity is accounted for by the superior category hotels, equipped with comfortable rooms, sports facilities, wellness centers and, where space allows, large halls for so-called congress tourism (i.e., exhibitions, conferences, seminars, conferences, workshops, etc.). However, in general, the hospitality establishments located in the spa resorts are characterized by high quality standards, not just the hotels owned by the spas. In fact, in spa resorts, the share of hotel accommodation is $72 \%$ and that of non-hotel facilities is $28 \%$, against a national average of $45 \%$ and $55 \%$, respectively. In the locations in question, the hotels with at least three stars represent almost $90 \%$ of the total, against a national average of less than $80 \%$.

Taking into account the marked geographical concentration of entrepreneurial activities (Figure 1), it is possible to divide the entire national territory into four areas: the first comprising the firstranked regions, which are at the top of the ranking by number of spas, namely Campania (96), Veneto (92), Emilia Romagna (23), and Tuscany (21); the second includes the regions that are posi- 
tioned immediately after the leading group, namely Lazio (15), Lombardy (14), Piedmont (10), and Trentino-Alto Adige (9); the third includes the regions that are located in an intermediate position, namely Marche (8), Calabria (6), Sardinia (6), and Sicily (5), and finally, the fourth includes the regions that are located at the bottom of the ranking in question, namely Friuli-Venezia Giulia (3), Abruzzo (3), Puglia (3), Valle d'Aosta (2), Umbria (2), Basilicata (2), and Liguria (1) (Figure 6).

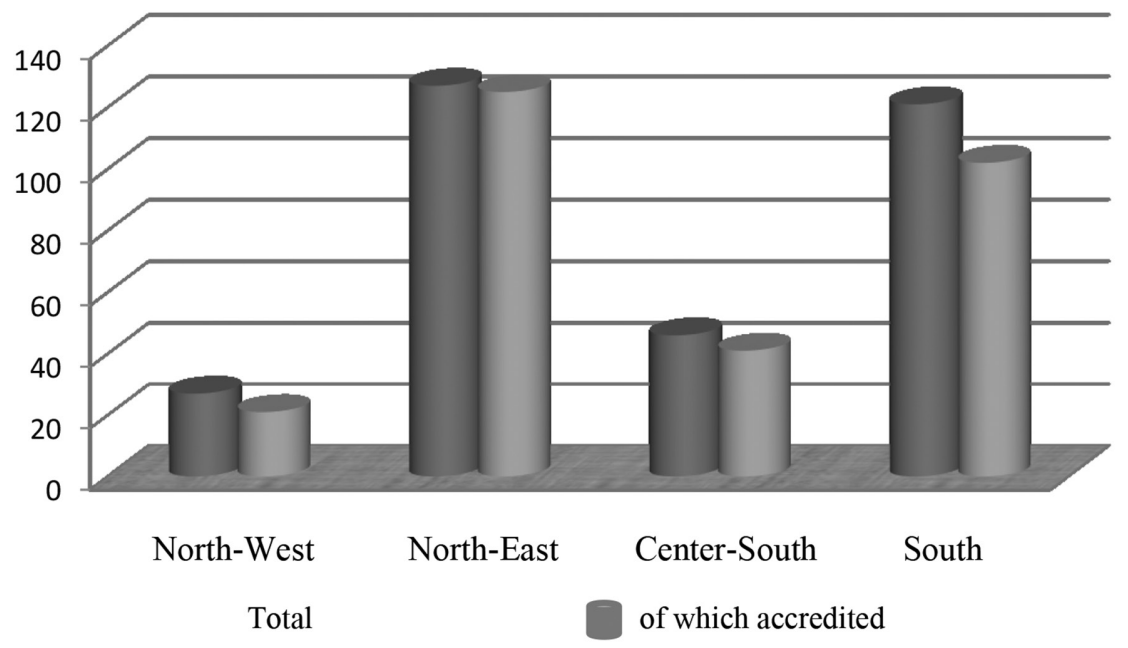

Figure 5. Number of thermal establishments for territorial districts in Italy Source: Ebiterme, 2018

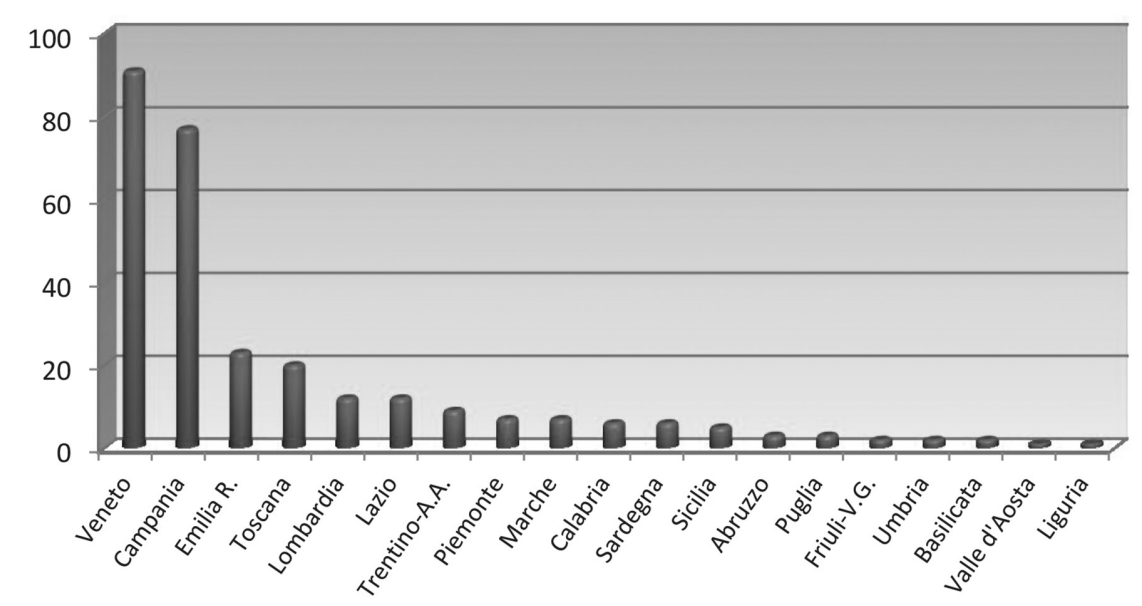

Figure 6. Ranking of regions by number of accredited spas in Italy

Source: Ebiterme, 2018

The four spas in Apulia (Figure 7) are the Terme di Castelnuovo della Daunia in the province of Foggia; the Terme di Margherita Savoia (Barletta-Andria-Trani); the Terme di Torre Canne in the province of Brindisi and the Baths of Santa Cesarea (Lecce). The second represents a particularly interesting case study due to its geographical location and the related tourist implications. The history of Margherita di Savoia is the story of its primary resource: the sea. The city has always lived in perfect symbiosis with the history of its 'Salina' (it's made up of a vast expanse of still water divided into pools for the production of sea salt), which determined its current economic and social situation. Over time, the socio-economic dichotomy between the city and the Salina has turned into multipolarity: the Salina, the baths, the reserve, the inhabited center. The territory of Margherita di Savoia covers an area of 360,000 hectares, of which almost 400 constitute the inhabited center and the remaining part is occupied by the Salina. 


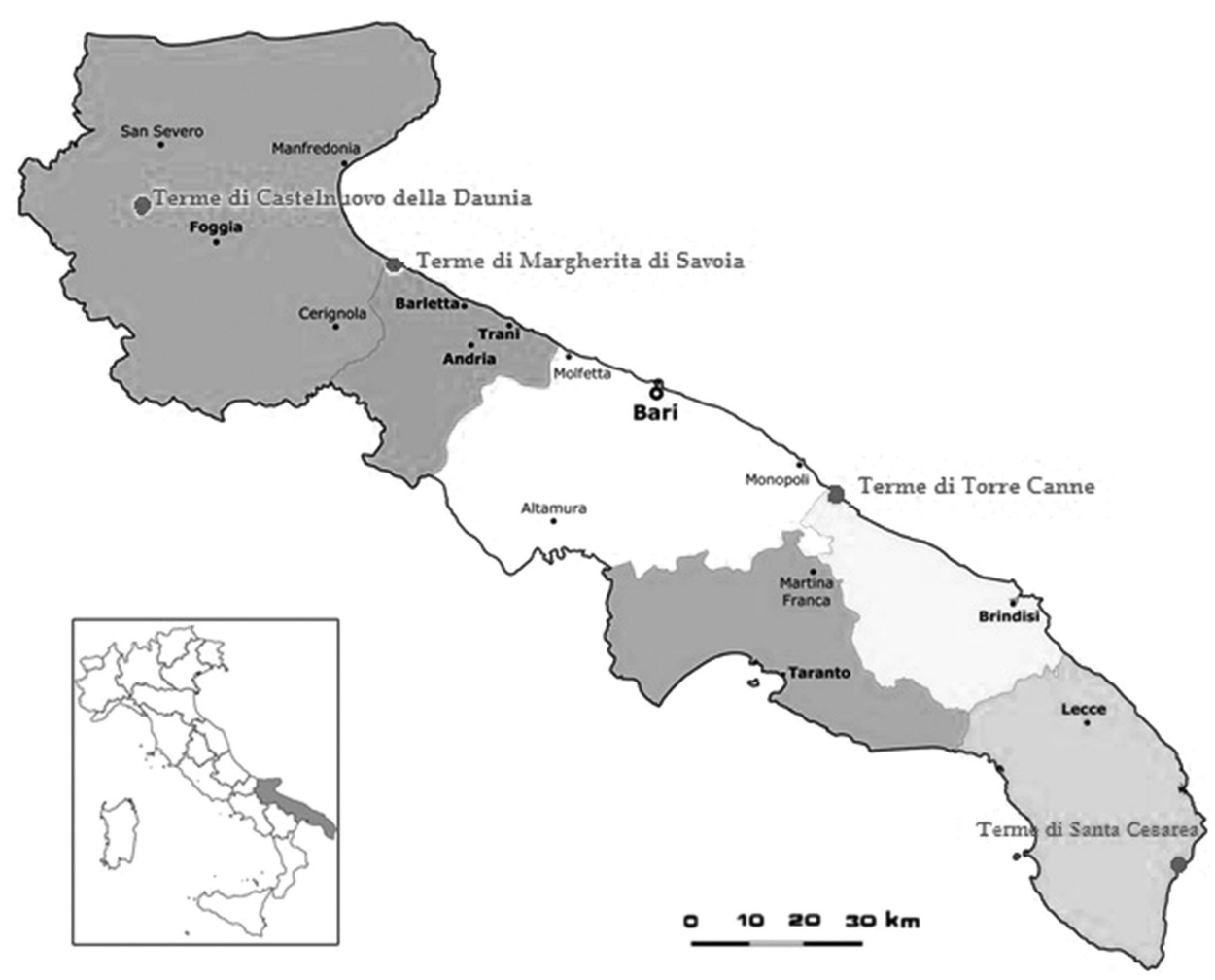

Figure 7. Spas in Apulia, Italy

Source: Ivona, 2019

The population is 11,885 inhabitants (2018 data of Italian Institute of National Statistic), with a decrease recorded in the last 15 years of almost $8 \%(12,677$ inhabitants in 2002) and a population density of 329.74 per square kilometer. Unlike the remaining Tavoliere and, more generally, the Province of Foggia to which Margherita belonged until 10 years ago (whose climate is warm temperate with tendencies to continentality, due to the protection of the Apennines to the west, the Gargano Promontory to the north and the Murge to the south, and to the rebalancing effect of the Adriatic Sea), the coastal plain represents a climatic island with particular peculiarities especially as regards rainfall. The annual rainfall is between $450-500 \mathrm{~mm}$. Average monthly temperatures are between $8.8^{\circ} \mathrm{C}$ in February and $26.9^{\circ} \mathrm{C}$ in July; the average is around $17.6^{\circ} \mathrm{C}$. Evaporation is $340 \mathrm{~mm}$ in July and $90 \mathrm{~mm}$ in the December-January period; in total the year shows values higher than 2,300mm (Palmisciano et al., 2000).

The aforementioned climatic conditions (low rainfall and high salinity conditions) and the particular morphology (a flat space with depressions that allow the entry of sea water into the evaporation tanks due to a natural gradient) of this part of the Apulian territory are among the factors that favored the initial location of the Salina and later induced their greater transformation and enhancement.

It could be said that the life of the Margheritans has always been linked to that of the Salina, so much so that, in some official documents of the past, the name of the inhabitants was Salinars. The increasing mechanization introduced in the salt production cycle obviously had negative consequences on employment within the Salina. Over the years, employment has shrunk dramatically; from the approximately 660 employees of the beginning of the 1980 s to the current 130 . The greatest contraction of jobs has concerned, above all, the workers but the reduction over the years in the number employed among administrative and managerial staff has been less drastic but constant. 
These data, then, appear even more negative if we consider the amount of employment in the 1960s and 1970s, when manual and annual harvesting employed around 500 permanent and 2,000 seasonal workers, who together accounted for $15 \%$ of the Margheritan population of that period (almost 13,000 inhabitants). The number of available jobs was so high that it was necessary to resort to workers from other municipalities. Although the prevailing activities were fishing and agriculture, the months of seasonal work at the Salina represented a source of income supplementation of considerable value for the entire Margheritan community. The Salina of Margherita di Savoia is the most important and extensive saline of marine origin in Europe. It extends for $20 \mathrm{~km}$ along the Adriatic coast and covers an area of 4,500 hectares, of which 3,500 hectares is evaporating pools, 500 hectares is saline basins, with an annual production of about 500,000 tons of salt.

Currently the main activity connected to the Salina is that of the Baths that use the mother water and the mud of the Saline. In 1991, the agreement with the National Health Service ceased to exist and this has led to a considerable decrease in attendance at the spa; despite this, the average attendance recorded in the six months of opening (from May to October) is around 30,000 , with an average annual increase of 3\%. La Salina, whose origins date back to $200 \mathrm{BC}$, is also declared a Wetland of international importance, pursuant to the Ramsar Convention; it is the largest animal population natural reserve in Central-Southern Italy, where between 20,000 and 50,000 species of fish and birds coexist. With its 3,871 hectares of surface, the Salina represents the largest regional extension (71\%) of humid environments with shallow waters and mud expanses. Over the years, however, the 'City of Salt' has turned into something else, into something not well-defined in the awareness, and in the behaviors, of its inhabitants and of the leading groups of the community. In terms of income, there is no doubt that tourism in its many forms (seaside, thermal, cultural) is, and must be, the driving force of the local economy, as has happened in other salt cities. The first spa with modern criteria was built in 1930 and was owned by the municipality, while in 1947 the privately managed thermal baths were built and, in 1988, they were modernized and brought up to European standards.

The center uses the mother water and the mud contained in the basins for the extraction of the salt. The sludge is mineralized in contact with the mother water. They are also enriched, always in a natural way, by the organic components provided by the microalgae and by the small crustaceans contained in the basins. Given the size of the Salina, the supply of sludge to the spa is constant. The empirical use of mother water for healing purposes is confused with the evolution of the municipality itself, so much so that its use can be traced back to Hannibal himself in 210 BC. Until the opening of the thermal establishment, and even in the following years, many people used to dive in drains with a muddy bottom of the residual waters, without any medical supervision. In thermal waters it is, instead, expected that the mother water is diluted with water heated to this gradation, in such a way as to allow a more rational therapeutic use. This is because temperature, degree of concentration, and immersion times are different according to the pathologies considered. The same procedure is also applied to the sludge, which is deposited in special tanks and mixed there. The current and modern facilities cover an area of 15,000 square meters. Numerous departments are provided for various types of care.

The economic development of Margherita di Savoia until the 1970s was positively influenced by the thermal activity; subsequently, seaside and second-home tourism developed considerably. At the beginning of the new millennium, in addition to tourists mainly of local origin, tourists of international origin also visited, with a constant rate of increase. Some analyses carried out 
(Rinella, 2019) testify to the importance that thermal activity has played in the birth and development of this locality and how much it has been able to actualize this attractive heritage, placing it at the center of its development strategies, considering it as a structural invariant that is an "essential component of the territory around which individual and collective initiatives are developed, and from which all local development strategies depart" (Rinella, 2019, p. 52), and striving to make the tourism product recognizable through the strengthening of the virtual image, now considered essential to "improve the effectiveness of tourism communication and strategies for commercial penetration on the main markets for irradiation of demand" (Rinella, 2019, p. 53). Today, more than ever, spa resorts it is essential, beyond the integration with the wellness sector, to take a further step aimed at creating a more meaningful connection with the surrounding locality: the competitive challenge can only be won based on the organizational ability of the tourist space as a whole, as it is precisely the changes that have occurred in the overall scenario that make it necessary to formulate strategic responses that are not only functional, but regional, in order to transform the Baths of Margherita di Savoia into a lasting opportunity for local regional development.

To complete the summary of the Apulian spas, a brief mention of the other centers. The thermal baths of Castelnuovo della Daunia use the mineral water from the "La Cavallina" spring. Hydropinic treatments are carried out for diseases of the digestive system. The entire complex is in the process of being completely renovated to expand the services offered also through new soil perforations which will allow greater extraction of water from the underground source. The others two spas, Torre Canne e Santa Cesarea are located in the southern part of Apulia in the sub-region of Salento which, in recent years, has recorded the highest number of tourists. The Baths of Torre Canne are affiliated with the National Health Service and classified as the first 'super' level; they offer treatments for respiratory tract and ear, for rheumatic and orthopedic diseases (mud-balneotherapy), for vascular diseases (walkways), physiotherapy and rehabilitation, and beauty treatments. The knowledge of the therapeutic virtues of the waters of Torre Canne goes back over a century. At the Terme di Torre Canne there are 11 pools coming from underground waterways and two of these have been particularly studied on the physical-chemical and therapeutic side: the number 11 pool, named Torricella, and the number three pool, named Antesana, have been recognized as having important properties for the health and wellbeing of the body. In the drainage channel and in the ponds originating from the springs there is a mud deposit formed by millennia that, thanks to the maturation in the thermal waters, has valid therapeutic properties. It is natural mud composed mainly of calcium alumina silicate and iron. Further south, on the coast between Otranto and Santa Maria di Leuca, are the Baths of Santa Cesarea. The origin of the thermal springs of Santa Cesarea dates back to the 16th century when the healing properties of the waters of Santa Cesarea were attested, but it was not until the end of the 19th century that their exploitation became systematic, thus beginning the tradition of the Baths of Santa Cesarea. The thermal waters of this area gush out within four coastal caves, at a temperature of about $30^{\circ} \mathrm{C}$. They are particularly indicated for the treatment of dermatological, gynecological and respiratory diseases.

\section{CONCLUSION}

Thermal tourism could be an interesting development tool for some regions and countries, if based on themed, resource-based, co-creation opportunities, presented in an appealing format, together with wellness tourism. In fact, there are revenue-earning business establishments associated with the wellness, recreational, and therapeutic uses of waters with special properties. 
Italy has a particular quality, which is important for health tourism, namely the availability of natural potential for the development in any direction in this field. Thermal tourism in Italy was not established with that purpose, and it requires a sound knowledge of the market to successfully cater to market segments that are interested in the experience. Heterogeneity in demand and distinct economic potentialities may be relevant to determining the most important target markets and corresponding positioning and product development. In fact, in the spa resorts, a higher share of the accommodation capacity is absorbed by the hotels, especially those in a higher quality category, is one of the reasons that evidences the greater economic impact of wellness tourism compared with the other components of tourism.

\section{REFERENCES}

Dai Prà, E. (2013). Geografie del benessere. La riqualificazione ecosostenibile del comparto termale e patermale in Trentino. Milano: Franco Angeli.

Diener, E., Suh, E. M., Lucas, R. E., \& Smith, H. L. (1999). Subjective well-being: Three decades of progress, Psychological Bulletin, 125, pp. 276-302.

Ebiterme (2018). L'economia del settore termale. Rapporto 2017, www.federterme.it, Accessed October 2019.

GWI, Global Wellness Institute (2018). Global Wellness Economy Monitor, October. https:// globalwellnessinstitute.org/wpcontent/uploads/2019/04/GWIWellnessEconomyMonitor2018_042019.pdf.

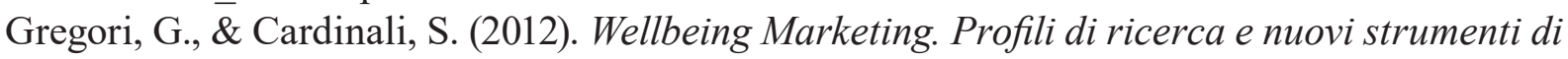 gestione nel mercato del benessere. Milano: Franco Angeli.

ISTAT (2017). Cittadini, Imprese e ICT, Statistiche, report, pp. 1-27.

Ivona, A. (2019). Scelte geoeconomiche per la valorizzazione del territorio. Opportunità e vincoli dall'entroterra al mare. Bari: WIP Edizioni.

Kervankiran, I. (2016). Between Traditional and Modern: Thermal Tourism in Turkey. In I. Egresi (Eds.), Alternative Tourism in Turkey (pp. 109-124). AG: Springer International Publishing.

Lo, C. (2019). Self and cultural preservation through spa and wellness tourism: an interview with Laura Ell, https://www.travindy.com/2019/09/self-and-cultural-preservation-throughspa-and-wellness-tourism-an-interview-with-laura-ell/.

Nawijn, J. (2011). Determinants of Daily Happiness on Vacation. Journal of Travel Research, 50(5), pp. 559-566.

Palmisciano, M., Quaranta, M., \& Russo, E. (2000) (Ed). La zona umida della Salina di Margherita di Savoia, Trinitapoli (FG): Centro Regionale di Servizi Educativi e Culturali.

Privitera, D. (2014). Gli stabilimenti termali nello spazio virtuale. La percezione dei visitatori on-line. Geotema, 46, pp. 160-165.

Puczkó, L., \& Smith, M. (2018). The Tourism Observatory for Health, Wellness and Spa, 5th International Wellness, Spa \& Travel Monitor, pp. 1-42.

Puglia Promozione (2019). Il turismo in Puglia 2019/2020, www.agenziapugliapromozione.it.

Quintela, J.A., \& Costa, J.C.M. (2015). Health and Wellness Tourism - A Strategic Plan for Tourism and Thermalism valorization of São Pedro do Sul. In M. Peris-Ortiz \& J. Álvarez García (Eds.), Health and Wellness Tourism: Emergence of a New Market Segment. Switzerland: Springer International Publishing.

Ramos, A., \& Santos, A. (2002). The Quality and Innovation in Thermal Tourism Destinations. https://pdfs.semanticscholar.org/520d/066522e0a7ae0b73bc0f94c9fle113dbe456.pdf. 
Rinella, F. (2019). Le Terme di Margherita di Savoia: volano per lo sviluppo locale?. In A. Ivona (Eds), Scelte geoeconomiche per la valorizzazione del territorio. Opportunità e vincoli dall'entroterra al mare (pp. 52-56). Bari: WIP Edizioni.

Rocca, G. (2014) (Ed). Dal Convegno di Aosta al Convegno di Catania: l'avanzamento degli studi condotti dal Gruppo di lavoro A.Ge.I., Geotema, 46, pp. 12-19.

Tabacchi, M.H. (2010). Current research and events in the spa industry. Cornell Hospitality Quarterly, 51(1), 102-117.

Tabayashi, A. (2010). Regional development owing to the commodification of rural spaces in Japan, Geographical Review of Japan Series B, 82(2), pp. 103-125.

Thielmann, T. (2010). Locative Media and Mediated Localities. An Introduction to Media Geography. Aether, The Journal of media geography, 2, pp. 1-17.

UNWTO (2019). World Tourism Organization and Global Tourism Economy Research Centre, UNWTO/GTERC Asia Tourism Trends - 2019 Edition, Executive Summary, Madrid: UNWTO.

Virtuoso Life (2017). 7 Big Trends in Wellness Tourism to Experience Now. http://blog.virtuoso. com/tips-and-trends/7-trends-wellness-tourism-experience-now/. 